\title{
Karnavala katılım öncesi ve sonrası destinasyon imajı algılarının karşılaştırması
}

\author{
Comparison of perceptions of destination ımage before and after participation in carnival
}

\author{
Sevda Sahilli Birdir ${ }^{1}$ ve Kemal Birdir ${ }^{2}$
}

${ }^{I}$ Doç. Dr., Mersin Üniversitesi, Turizm Fakültesi, Mersin / Türkiye, birdirss@mersin.edu.tr, ORCID: https://orcid.org/0000-0002-1568-5837 ${ }^{2}$ Prof. Dr., Mersin Üniversitesi, Turizm Fakültesi, Mersin / Türkiye, kemalbirdir@mersin.edu.tr, ORCID: https://orcid.org/0000-0003-13533618

\begin{tabular}{|c|c|}
\hline Makale Bilgisi & $\ddot{O}_{z}$ \\
\hline $\begin{array}{l}\text { Gönderilme: } 3 \text { Şubat } 2021 \\
\text { Düzeltme: } 17 \text { Haziran } 2021 \\
\text { Kabul: } 22 \text { Haziran } 2021 \\
\text { Anahtar kelimeler: } \\
\text { Katılım öncesi, } \\
\text { Katılım sonrasi, } \\
\text { Destinasyon imajl, } \\
\text { Portakal Çiçeği Karnaval, } \\
\text { Adana }\end{array}$ & 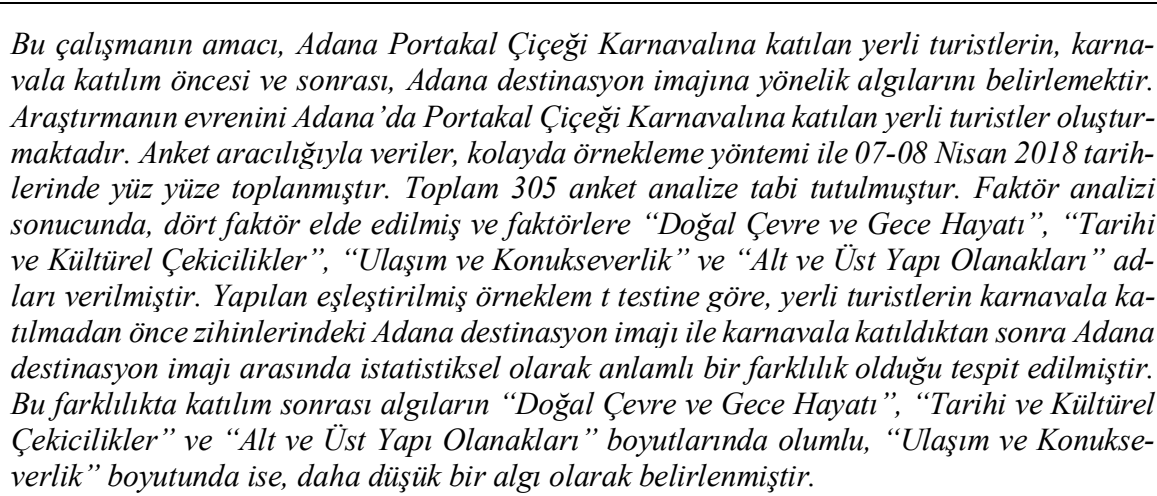 \\
\hline
\end{tabular}

\begin{tabular}{|c|c|}
\hline Article Info & Abstract \\
\hline Research Article & $\begin{array}{l}\text { The aim of this study is to determine the perceptions of local tourists attending Adana Or- } \\
\text { ange Blossom Carnival towards Adana destination image before and after participating in }\end{array}$ \\
\hline $\begin{array}{l}\text { Received: } 3 \text { February } 2021 \\
\text { Revised: } 17 \text { June } 2021 \\
\text { Accepted: } 22 \text { July } 2021\end{array}$ & $\begin{array}{l}\text { the carnival. The universe of the research consists of local tourists participating in the Or- } \\
\text { ange Blossom Carnival in Adana. Data were collected face-to-face through the survey on } \\
07-08 \text { April } 2018 \text { using the convenience sampling method. A total of } 305 \text { questionnaires } \\
\text { were analyzed. As a result of the factor analysis, four factors were obtained and the factors }\end{array}$ \\
\hline Keywords: & were named as "Natural Environment and Nightlife", "Historical and Cultural Attractions", \\
\hline Pre-participation, & "Transportation and Hospitality" and "Infrastructure and Superstructure Facilities". Ac- \\
\hline Post-participation, & cording to the paired sample t test, it was determined that there is a statistically significant \\
\hline Destination image, & difference between the Adana destination image in the minds of local tourists before and \\
\hline $\begin{array}{l}\text { Orange Blossom Carnival, } \\
\text { Adana }\end{array}$ & $\begin{array}{l}\text { after joining the carnival it was determined that the post-participation perceptions were } \\
\text { positive in the dimensions; "Natural Environment and Nightlife", "Historical and Cultural } \\
\text { Attractions" and "Infrastructure and Superstructure Facilities", and a lower perception in } \\
\text { the "Transportation and Hospitality" dimension. }\end{array}$ \\
\hline
\end{tabular}

\section{Giriş}

Destinasyon alg1sı, bir bireyin ilgi duyduğu bir yerin zihinsel temsilini veya izlenimini ifade eder (San Martin \& Del Bosque, 2008). Destinasyon algısı, destinasyon seçimine etki etmekte ve destinasyon seçimi, turistlerin ihtiyaç ve zevklerine göre belirlenen seyahat isteklerinden ve bu ihtiyaç ve arzuların karşılanması için mevcut destinasyonların sunduğu ürünlerle belirlenmektedir. Destinasyon imajı, bir turist destinasyonunun farklı yönlerinin olumlu ve olumsuz algılarının bir karışımı olarak ortaya çıkar (Wang \& Davidson, 2010:113). Bu olumlu veya olumsuz algılar, destinasyon seçim sürecindeki önemli unsurlardan bazılarıdır (Um \& Crompton, 1990: 433). Öte yandan, dünyanın birçok yerinde düzenlenen karnavallar, yapıldığı destinasyonun tanınırlılığını artırarak, destinasyonun imajına olumlu etkide bulunmakta ve destinasyona ekonomik, sosyal ve kültürel katkı sağlamaktadır

* Bu çalışmanın verileri 7-8 Nisan 2018'de toplanmıştır. Tüm sorumluluk yazarına aittir.

Kaynak göster: Sahilli Birdir, S. \& Birdir, K. (2021). Karnavala katılım öncesi ve sonrası destinasyon imajı algılarının karş1laştırmas1. International Journal of Social Sciences and Education Research, 7 (3), 274-284. DOI: https://doi.org/10.24289/ijs$\underline{\text { ser.890296 }}$ 
(Rivera vd., 2008:128 ; Kim vd., 2010:297; Axelsen \& Swan, 2010; Gül vd., 2013; Bekar, Kocatürk \& Sürücü, 2017:29-32). Böylece, karnavallar, turizm sezonun farklı dönemlerinde gerçekleştirilerek sezon dışında turistlerin destinasyonu ziyaret etmelerine olanak sağlamakta ve bu durum turizm sezonunun uzamasına olanak sağlamaktadir (Arcodia \& Dickson, 2013: 148).

Öte yandan, Adana'nın turizm imajı ile ilgili birçok çalışma (Saçlı \& Ersöz, 2019; Dinler, 2019; Ballı, 2016; Çeviker, 2019; Sahilli Birdir \& Toksöz, 2017) yapılmıştır. Dolayısıyla, gezilecek yerle ilgili ziyaret öncesi ve sonrası imaj ölçümüne odaklı farklılıkları belirleyen çok az araştırma yapılmıştır. Bu boşluğu gidermek için, bu çalışma, Adana'nın Portakal Çiçeği Karnavalı'na katılan turistlerin Adana'yı bir turist destinasyonu olarak algılamasını ele almıştır. Çalışmada, katılımcıların karnaval katııımı öncesi ve sonrası algıları karşılaştırılarak elde edilen bulgulara dayalı olarak turizm işletmeleri ve destinasyon pazarlamacıları, bu pazarı daha etkili bir şekilde yönetmek ve iletişim kurmak için kullanabilirler.

\section{Alanyazin}

Karnavallar / festivaller özel, yöreye özgü, eğlenceli bir şekilde kutlanan etkinliklerdir. Karnavallar / festivaller bazen gösteri, bazen de eğlence ve tanıtım amaçlı yapılmakta ve insanları biraraya getirmektedir. İnsanlar, farklı amaçlarla festivallere katılmaktadırlar (Gibson, Conell, Waitt \& Walmsley, 2011:3). Penpece'ye (2014:194) göre festivaller, gerçekleştiği dönem ve katılımcıların sayısı ve niteliğine bağlı olarak değişiklik gösteren, sanat, kültür ve bilim gibi konularla gerçekleşen özel gösterilerdir. Karnavallar / festivaller, düzenlendikleri destinasyona birçok katkı sağlarlar. Bu katkılardan bazıları, karnavalın düzenlendiği destinasyonun tanınırlılığına yardımcı olması (Saçlı, Ersöz \& Kahraman, 2019:180), destinasyondaki turizm sezonunun uzatılması ve turizmin çeşitlendirilmesidir (Karagöz, 2006: 1).

Destinasyonlara yönelik yapılan festivaller hem bölge halkının kalkınmasına hem de bölgenin tanıtımı açısından önemli bir yere sahiptir. Festivallerin yeterli tanıtımı yapılması halinde, bölgeye gelen turist sayısı artmakta ve gelen turistlerin bölgedeki işletmelerden satın alma gerçekleştirmesi ile bölgedeki işletmelerin gelir kaynağ artmakta ve bu durum tüm bölgenin ekonomisine katkı sağlamaktadır (Tümbek Tekeoğlu \& Gökseven, 2019: $353)$.

Destinasyon imajına yönelik yapılan ilk çalışma Hunt (1975) tarafından yapılmış ve imajın turizmin gelişmesindeki rolüne odaklanmıştır. O günden bu yana destinasyon imajı halen tercih edilen bir çalışma alanıdır (Yılmaz, Yılmaz, İçigen, Ekin \& Utku, 2009). Echtner \& Ritchie’ye (1991) göre, destinasyon imajı, bir yere yönelik izlenimler veya gezilecek yerin oluşturduğu bütünsel bir algı olduğuna vurgu yapmışlardır. Crompton'a (1979) göre, bu algı, "bir yerle ilgili inanç, fikir ve izlenimlerin toplamıdır". Baloğlu \& McCleary (1999) destinasyon imajının turistlerin bir destinasyonla ilgili sahip oldukları izlenimler, bilgiler ve hisler'den oluştuğunu belirtmektedirler. Başka bir tanımda ise; insanlarda bir destinasyona yönelik zamanla oluşan duygular, hisler, fikirler ve izlenimler (Kim \& Richardson, 2003) olduğuna vurgu yapılmaktadır. Destinasyon imaj1; bilişsel (cognitive image) ve duygusal (affective image) imaj olmak üzere iki bileşenden oluşmaktadır. Bilişsel imaj, bir kişinin bir destinasyonla ilgili sahip olduğu bilgi veya inançlarını ele alırken (Baloğlu, 1999), duygusal imaj, bir kişinin bir destinasyona yönelik duygu ve / veya hislerini ele alır (Chen \& Uysal, 2002; Artuğer \& Çetinsöz, 2014:368; Çanakçı, Çanakçı \& Geçgin 2019:1879).

Yılmaz ve diğerlerinin (2009) yapmış olduğu çalışma, destinasyona yeni gelen turistlerle, destinasyondan ayrılan turistler arasında destinasyon imajı farklılıklarını incelemeyi amaçlamıştır. Çalışmada, 27 destinasyon özelliğinden altı faktör elde edilmiş ve faktörlere "Çevresel Koşullar", "Destinasyon Avantajları", "Faaliyetler", "Çekicilik", "Tesisler" ve "İklim" adları verilmiştir. Destinasyona yeni gelen turistlerle, destinasyondan ayrılan turistler arasında "Çevresel Koşullar", "Çekicilik" ve "İklim" faktörlerinde önemli farklılıklar olduğu tespit edilmiştir. Destinasyondan ayrılan turistlerin daha olumlu bir imaja sahip oldukları belirlenmiştir. Lim, Chew, Lim \& Liu'nin (2014) çalışmasının amacı, Singapurlu Y Kuşağı turistlerin Çin'e yönelik ziyaret öncesi ve sonrası algılarını ortaya koymaktır. Çalışmada, Çin'in destinasyon imajına yönelik altı faktör belirlenmiştir. Singapurlu genç turistlerin "Fiyat", “Altyapı", "Güvenlik", "Cazibe Merkezleri” ve "Sosyal Etkileşimler" boyutları altında toplanan destinasyon imajı algılarının ziyaret sonrası önemli ölçüde iyileştiğini tespit etmişlerdir.

Güçlü \& Yılmaz'ın (2020) Alanya'ya gelen yabancı turistlerin gezilen destinasyona yönelik seyahat öncesi ve sonrası algılarını belirlemek amacını taşıyan çalışmada, turistlerin imaj algı boyutlarının "Restoran Hizmetleri", "Plajlar", "Yerel Esnaf”, "Güvenlik ve Ulaşım”, "Yerel Halk", "Gece Hayatı", "Doğal ve Temiz Çevre", "Tarih ve Kültür" altında toplandığı belirlenmiştir. Elde edilen sonuçlara göre, turistlerin destinasyonu ziyaret sonrası kazandıkları imaj algısının ziyaret öncesi destinasyon imaj algısına oranla daha yüksek olduğu tespit edilmiştir. 
Saçlı \& Ersöz (2019) festival katılımcılarının Adana destinasyon imajı algılarının belirlenmesi amacıyla yaptıkları çalışmada, faktör analizi sonucunda, beş faktör elde edilmiş ve faktörlere "Memnuniyet”, "Yörenin Kültürü", "Fiziki Durum", "Festivalin Kente Katkıları" ve "Festivalin Yerel Halka Katkıları" adları verilmiştir. Destinasyon imajı algı boyutları ile katılımcıların demografik özellikleri arasında istatistiki açıdan anlamlı farklılıklar belirlenmiştir.

Wang \& Davidson (2010) Avustralya'nın Çin paket tatil pazarında bir turist destinasyonu olarak nasıl algılandığını belirlemeye çalışmışlardır. Turistlerin seyahat öncesi ve sonrası algılarını belirlemek için bir anket ile veriler toplanmıştır. Doğal manzara ve hoş çevre Avustralya'nın avantajları olarak tanımlanırken, müzeler, erişilebilirlik, alışveriş ve eğlence ile ilgili alanlar dezavantajlı olarak belirlenmiştir. Destinasyon algısının seyahat deneyimine göre şekilleneceğine vurgu yapılmıştır. Güçlü'nün (2017), Alanya'ya tatile gelen turistlerin tatil öncesi ve tatil sonrası destinasyon imajı farklılıklarını belirlemek amacıyla yapmış olduğu çalışmada, destinasyona yönelik imajın tatil öncesi ve tatil sonrasında farklılaştığını, bu farklılıkta, turistlerin katıldıkları faaliyetlerin önemli bir etkiye sahip olduğu belirlenmiştir. Bununla birlikte, tatil öncesi destinasyon imajında itici ve çekici seyahat motivasyonların etkili olduğunu, buna karşın, tatil öncesi destinasyon imajında bilgi kaynaklarının etkisi olmadığı tespit edilmiştir. Çeviker (2019), Adana'da turizm odaklı yapılan faaliyetlerin yerel halk tarafından nasıl değerlendirildiğini ve turizmin bölgeye olan ekonomik, sosyo-kültürel ve çevresel etkileri arasındaki farklılıkları belirleme amacını taşıyan bir çalışma gerçekleştirmiştir. Çalışma sonucunda, yerel halkın demografik özellikleri ile Adana'ya yönelik turizm algıları arasında anlamlı farklılıklar olduğu ve bölge turizminin gelişimini destekledikleri tespit edilmiştir.

Saçlı, Ersöz \& Kahraman (2019) tarafından yapılan çalışmanın amacı, karnavala katılanların Adana destinasyon imajına yönelik algılarının tekrar ziyaret etme niyeti üzerinde etkisi olup olmadığını ortaya koymak ve katılımcıların destinasyon imajı algılarının farklı olup olmadığını belirlemektir. Elde edilen bulgulara göre, karnaval katılımcılarının Adana destinasyon imajı algılarının destinasyonu tekrar ziyaret etme eğilimlerinin pozitif yönde anlamlı bir etkisi olduğu belirlenmiştir. Bununla birlikte, destinasyona yönelik imaj algılarının karnaval katılımc1ların demografik özelliklerine göre anlamlı farklılıklar olduğu belirlenmiştir. Yayla (2017) yöresel yemek festivallerinin destinasyon imajına yönelik etkisini ve Alaçatı Ot Festivaline katılanların gelecekteki davranışsal niyetlerini tespit etmek amaçlı bir çalışma yapmıştır. Çalışma sonucuna göre, katılımcıların sahip olduğu destinasyon imajı ve motivasyonlarının memnuniyet düzeyine ve davranışsal niyetleri üzerinde önemli bir etkisi olduğu belirlenmiştir.

\section{Yöntem}

\subsection{Araştırmanin amacl}

Festival ve/veya karnavalların yapıldıkları destinasyonlara olan etkilerin ele alındığı (Um \& Crompton, 1990: 433; Rivera vd., 2008:128 ; Kim vd., 2010:297; Axelsen \& Swan, 2010; Gül vd., 2013; Bekar, Kocatürk \& Sürücü, 2017:29-32) bir çok çalışma mevcuttur. Festival ve/veya karnavallar, gerçekleştiği destinasyonlar için gelenekselleşen, toplumda önemli bir yere sahip olan ve bir destinasyonun simgesine dönüşen etkinliklerdir (Saçlı, Ersöz \& Kahraman, 2019:180; Birdir, Toksöz \& Bak, 2016:23). Festivallerin dünyadaki örnekleri ele alındığında, festivallerin gerçekleştiği destinasyon için tek başına bir çekicilik unsuru (Rio Karnavalı gibi) olduğu görülmektedir. Bu açıdan, festival katılımcılarının algılarının belirlenmesi büyük önem taşımaktadır. Dolayısıyla bu araştırmanın amacı, VI. Uluslararası Portakal Çiçeği Karnavalı'na katılan yerli turistlerin karnavala katılmadan önce ve karnavala katıldıktan sonraki Adana destinasyon imajına yönelik algılarını tespit etmek ve karnavala katılmadan önceki ve karnavala katıldıktan sonraki Adana destinasyon imajı arasındaki farklılıkları ortaya koymaktır.

\subsection{Araştırma problemi ve sorularl}

Araştırmanın temel problemi "turistlerin karnavala katılmadan önce ve karnavala katıldıktan sonra Adana destinasyon imajına yönelik algılarında anlamlı bir farklılık vardır" ifadesidir. Bu ifadeden hareketle çalışmada aşağıdaki araştırma soruları geliştirilmiştir.

$\mathrm{AS}_{1}$ : Yerli turistlerin karnavala katılım öncesi ve karnavala katılım sonrası Adana destinasyon imajına yönelik algiları nelerdir?

$\mathrm{AS}_{2}$ : Yerli turistlerin karnavala katılmadan önceki Adana destinasyon imajına yönelik algı boyutları nelerdir?

$\mathrm{AS}_{3}$ : Yerli turistlerin karnavala katıldıktan sonraki Adana destinasyon imajına yönelik algı boyutları nelerdir?

$\mathrm{AS}_{4}$ : Yerli turistlerin karnavala katılım öncesi ve karnavala katılım sonrası destinasyon imajı algıları arasında anlamlı bir farklılık var midır? 


\subsection{Ana kütle ve örneklem}

Araştırmanın evrenini, 6. Uluslararası Portakal Çiçeği Karnavalı'na katılan yerli katılımcılar oluşturmaktadır. Ancak hem zaman hem de maddi kaynak yetersizlikleri nedeniyle, evreni temsil yeterliliğine sahip örnek kütle seçimine gidilmiştir. Evreni temsil yeterliliğine sahip örnek kütlenin seçimi için, resmi kaynaklar incelenmiştir. Uluslararası Portakal Çiçeği Karnavalına 2013'te 50.000 kişi, 2014'te 140.000 kişi ve 2015'te 350.000 kişi katılmış olup, 2018 yılında ise, Adana dışından gelen turistlerle ve Adana halkının da içinde olduğu yaklaşık 1 milyon kişinin karnavalı deneyimlediği belirlenmiştir (www.nisandaadanada.com, 2018). Örnek kütlenin belirlenmesinde basit tesadüfi örnekleme yöntemi formülünden $\left(\mathrm{n}=\mathrm{t}^{2}\right.$.p.q $/ \mathrm{d}^{2}$ ) yararlanılarak (Yazıcıoğlu \& Erdoğan, 2004: 48), örneklem büyüklüğü, \%95 güven düzeyinde ve $\pm 0.05^{\prime}$ lik sapma aralığ ile $n=(1.96)^{2} \times(0.5) \times(0.5) /(0.05)^{2}=384$ kişi olarak hesaplanmıştır. Araştırmada, tesadüfi olmayan örnekleme yöntemlerinden "kolayda örnekleme yöntemi" tercih edilmiştir. Bu yöntemde örnek birimlerinin seçimi gönüllülük esasına bağlı olduğundan, ankete cevap vermek isteyenlerin örnek birimine alınabileceği ifade edilmektedir (Yükselen, 2000:69; Nakip, 2003:184; Coşkun vd., 2007:142). Dolayısıyla, veriler, anketi gönüllü doldurmak isteyen yerli turistlerden toplanmıştır.

\subsection{Veri toplama yöntemi}

Araştırmada, nicel araştırma yönteminden yararlanılmıştır. Araştırmada, veri toplama yöntemi tekniklerinden bir olan anket tekniğinden faydalanılmıştır. Anket dört bölümden oluşmakta olup, anketin birinci ve ikinci bölümünde Portakal Çiçeği Karnavalına katılmadan önce ve karnavala katıldıktan sonra Adana'ya yönelik sahip olunan değerlendirmeleri içeren 26 maddeden oluşan imaj ölçeği yer almıştır. Ölçeğin geliştirilmesinde Beerli \& Martin (2004), Lee, Kyle \& Scot (2012) ve Benli (2014)'nin çalışmalarından faydalanılmıştır. Anketin üçüncü bölümünde kullanılan ölçek, katılımcıların Portakal Çiçeği Karnavalı'na yönelik düşüncelerin belirlenmesine yönelik olup, ölçeğin geliştirilmesinde, Wong, Wu \& Cheng (2014), Wu \& Ai (2015) ve Anil (2012)'ın çalışmalarından faydalanılmıştır. Anketin son bölümünde, katılımcıların demografik özelliklerini belirlemek için açık ve kapalı uçlu sorular sorulmuştur. Ancak, bu çalışmada, karnavala katılan yerli turistlerin karnavala katılmadan önceki ve karnavala katıldıktan sonraki Adana destinasyon imajına yönelik algıları ele alınmıştır.

Araştırmada, geliştirilen anket formunun güvenirliliğini test etmek için 16 yerli turist ile ön test (06 Nisan 2018) yapılmıştır. Araştırmada, Cronbach $\alpha$ güvenirlilik (Cronbach, 1990) analizinden yararlanılmıştır. Ön test sonuçlarına göre, karnavala katılım öncesi destinasyon imajı Cronbach Alpha değeri 0,908, karnavala katılım sonrası destinasyon imajı Cronbach Alpha değeri ise, 0,923 olarak belirlenmiştir. Bu sonuçlar 1şığında, geliştirilen anket formunun güvenirlilik açısından yeterli olduğu bulgulanmıştır. Araştırmanın ana uygulaması için veriler $07-$ 08 Nisan 2018 tarihlerinde yüz yüze toplanmıştır. Katılımcılardan toplam 320 anket geri toplanmış olup, 305 anket analize tabi tutulmuştur. Anketlerin $15^{\prime}$ i eksik veri nedeniyle analize dahil edilmemiştir. Ana uygulama için yapılan güvenirlilik analizine göre, karnavala katılım öncesi destinasyon imajı Cronbach Alpha değeri 0,928, karnavala katılım sonrası destinasyon imajı Cronbach Alpha değeri ise, 0,927 olarak tespit edilmiştir.

\subsection{Analiz}

Araştırmada öncelikle tanımlayıcı analizler yapılmıştır. Daha sonra, karnavala katılım öncesi ve karnavala katılım sonrası destinasyon imajı algılarının boyutlarının belirlenmesi için faktör analizi yapılmıştır. Ayrıca, turistlerin destinasyona gelmeden önce ve destinasyonu deneyimledikten sonra sahip olunan destinasyon imajı alg1larını karşılaştırmak için t testi yapılarak, elde edilen sonuçlar doğrultusunda bulgular yorumlanmıştır.

\section{Bulgular}

Araştırmaya katılan yerli turistlerin demografik bilgileri Tablo 1'de görülmektedir. Tabloya göre, katılımcıların \% 49,5'i “kadın” ve \%50,5'i “erkek”tir. Katılımcıların \%56,7'si “bekar” ve \%43,3'ü evli olup, \%50,4'ü “2130 ” yaş aralığındadır. Bunu, \%23,8'lik bir oranla “ $31-40 ”, \% 16$ 'lık bir oranla “41-50” ve \%9,8'lik bir oranla "51 ve üstü” yaş aralığındaki katılımcılar izlemektedir. Katılımcıların eğitim durumları ele alındığında, en yüksek oranın üniversite (\%63) mezunlarına ait olduğu görülmektedir. İkinci büyük oran, ilköğretim ve lise mezunlarına $(\% 25,2)$ aittir. Bunları, \%11,5'lik bir oranla "lisansüstü” mezunları takip etmektedir. Katılımcıların çoğunluğunun "öğrenci $(\% 26,2)$ " olduğu bulgulanmıştır. Bunu sırasıyla, "serbest meslek $(\% 23,6)$ ", "memur $(\% 17,7)$ ", "diğer $(\% 11,8)$ ", "yönetici $(10,5)$ ” ve "işçi $(\% 9,8)$ ” olan katılımcılar izlemektedir. Katılımcıların gelir düzeyleri incelendiğinde, \%58,4’ünün “orta” gelir grubunda oldukları tespit edilmiştir. “Ortanın üstü” gelir grubunda olan katılımcıların oranı, \%25,6, “ortanın altı” gelir grubunda olan katılımcıların oranı \% 7,5, "yüksek” gelir grubunda olan katılımcıların oranı, \%6,9 ve “düşük” gelir grubunda olan katılımcıların oranı ise, \%1,6' dır. 
Tablo 1. Uluslararası Portakal Çiçeği Karnavalına katılanların demografik özellikleri

\begin{tabular}{|c|c|c|c|c|c|c|c|c|c|c|c|}
\hline Cinsiyet & $f$ & $\%$ & Yaş & $f$ & $\%$ & Medeni Durum & $\mathrm{f}$ & $\%$ & Ĕ̈itim Durumu & $\mathrm{f}$ & $\%$ \\
\hline Kadın & 151 & 49,5 & $21-30$ & 154 & 50,4 & Bekar & 173 & 56,7 & İlköğretim ve Lise & 77 & 25,2 \\
\hline Erkek & 154 & 50,5 & $31-40$ & 73 & 23,8 & Evli & 132 & 43,3 & Üniversite & 192 & 63 \\
\hline \multirow[t]{3}{*}{ Toplam } & 305 & 100 & $41-50$ & 48 & 16 & Toplam & 305 & 100 & Lisansüstü & 35 & 11,5 \\
\hline & & & 51 ve üstü & 30 & 9,8 & & & & Belirtmeyen & 1 & 0,3 \\
\hline & & & Toplam & 305 & 100 & & & & Toplam & 305 & 100 \\
\hline Meslek & $f$ & $\%$ & Gelir Düzeyi & $f$ & $\%$ & Katılım şekli & $\mathrm{f}$ & $\%$ & $\begin{array}{l}\text { Daha önce karna- } \\
\text { vala katıldınız mı? }\end{array}$ & $\mathrm{f}$ & $\%$ \\
\hline Serbest $\mathrm{m}$ & 72 & 23,6 & Düşük & 5 & 1,6 & Yalnız & 15 & 4,9 & Evet & 164 & 53,8 \\
\hline Yönetici & 32 & 10,5 & Ortanın alt1 & 23 & 7,5 & Eşimle & 48 & 15,7 & Hayır & 141 & 46,2 \\
\hline İşçi & 30 & 9,8 & Orta & 178 & 58,4 & Ailemle & 61 & 20 & Toplam & 305 & 100 \\
\hline Memur & 54 & 17,7 & Ortanın üstü & 78 & 25,6 & Arkadaşlarla & 181 & 59,4 & & & \\
\hline Öğrenci & 80 & 26,2 & Yüksek & 21 & 6,9 & Toplam & 305 & 100 & & & \\
\hline Diğger & 36 & 11,8 & Toplam & 305 & 100 & & & & & & \\
\hline Belirtmeyen & 1 & 0,3 & & & & & & & & & \\
\hline Toplam & 305 & 100 & & & & & & & & & \\
\hline
\end{tabular}

Katılımcıların \%53,8'inin daha önce Portakal Çiçeği Karnavalına katıldıkları belirlenmiştir. Dolayısıyla, karnavala ilk defa katılanların oranı \%46,2 olarak gerçekleşmiştir. Karnavala kiminle katıldınız sorusuna alınan cevaplar incelendiğinde, karnavala "arkadaşları" ile katılanların oranının \%59,4 ile en yüksek oran olduğu görülmektedir. Bunu sırasıyla, karnavala "ailesiyle (\%20)", “eşiyle $(\% 15,7)$ ” ve "yalnız $(\% 4,9)$ ” katılanlar takip etmiştir.

$\mathrm{AS}_{1}$ : Yerli turistlerin karnavala katılım öncesi ve karnavala katılım sonrası Adana destinasyon imajına yönelik algiları nelerdir?

Tablo 2'de gösterildiği gibi, karnavala katılım öncesi en iyi beş destinasyon imajı algı unsuru "Adana halkı misafirperver ve dost canlısıdır”, "Adana ulaşımı kolay bir şehirdir”, "Adana alışveriş olanaklarına yeterince sahip bir şehirdir", "Manzara güzelliğine sahip bir şehirdir" ve "Başkalarının Adana’yı ziyaret etmesini tavsiye ederim" unsurlarıdır. Karnavala katılım sonrası algılanan en iyi beş destinasyon imajı unsurunun "Adana halkı misafirperver ve dost canlısıdır", "Başkalarının Adana’yı ziyaret etmesini tavsiye ederim”, “Adana dinlenme alanları mevcut olan bir şehirdir", "Manzara güzelliğine sahip bir şehirdir" ve "Adana hakkında başkalarına olumlu şeyler söyleyebilirim” unsurları olduğu görülmektedir. Karnavala katılım öncesi en iyi ortalamaya sahip Adana'nın çekicilik ve konukseverlik unsurlarının karnavala katılım sonrası algıda benzer sonuçlara sahip olduğu görülmektedir.

Festivale katılım öncesi algılanan en düşük beş destinasyon imajı unsurunun "Adana güvenli bir şehirdir", “Adana lüks bir şehirdir”, “Adana gelişmiş üst yapıya sahip bir şehirdir”, “Adana gelişmiş alt yapıya sahip bir şehirdir" ve "Adana günümüzün moda şehridir” unsurları olduğu belirlenmiştir. Festivale katılım sonrası algılanan en düşük beş destinasyon imajı unsurunun ise, “Adana lüks bir şehirdir”, “Arkadaşlarımın çoğu Adana’yı diğer yerlere tercih ediyor", "Adana gelişmiş üst yapıya sahip bir şehirdir”, "Adana günümüzün moda şehridir" ve “Adana gelişmiş alt yapıya sahip bir şehirdir” unsurlarıdır. Festivale katılım öncesi algıya benzer şekilde en düşük ortalamaya sahip Adana'nın alt ve üst yapı olanakları ile ilgili unsurları festivale katılım sonrası algıda son beş sırada yer almıştır.

$\mathrm{AS}_{2}$ : Yerli turistlerin karnavala katılmadan önceki Adana destinasyon imajına yönelik algı boyutları nelerdir?

Katılımcıların, algılanan destinasyon imajını belirlemek için ölçekte karnavala katılmadan önce ve karnavala katıldıktan sonra olmak üzere iki kısımda soru yöneltilmiştir. Karşılaştırma yapmak için öncelikle faktör analizi yapılmıştır. Karnavala katılmadan öncesi ve sonrası için açımlayıcı faktör analizi yapılırken elde edilen verilerin faktör analizi için uygunluğunda yeterli korelasyona sahip ve verilerden anlamlı faktörler çıkarılabileceği (Hair vd., 2010:105) Barlett Küresellik testi ile değerlendirilmiştir. Karnavala katılım öncesi Barlett Küresellik testinin $(3246,150)$ anlamlı sonuç vermesi $(p<0,000)$ ve örneklem sayısının faktör analizine uygunluğunu belirlemek için yapılan Kaiser-Meyer-Olkin testi $(0,937)$ sonucunda örneklem büyüklüğünün yeterli olduğu bulgulanmıştır. Toplam yirmialtı maddeye uygulanan faktör analizinde faktör yükleri ,50' den küçük, hiç yüklenmeyen (2,3,8,9,16, 22 nolu maddeler) ve birden fazla faktöre (17 nolu madde) yüklenen maddeler analizden çıkarılmıştır. Yapılan analize göre, 19 madde dört faktör üretmiştir. Bu faktörlere "Doğal Çevre ve Gece Hayatı", “Alt ve Üst Yapı Olanakları”, “Tarihi ve Kültürel Çekicilikler” ve "Ulaşım ve Konukseverlik” isimleri verilmiştir (Tablo 3). Dört faktör, toplam varyansın \%66'sını açıklamaktadır. 
Tablo 2. Festivale katılım öncesi ve sonrası destinasyon imajı algılama niteliklerinin ortalama sıralaması

\begin{tabular}{|c|c|c|c|c|c|c|}
\hline Destinasyon İmaj1 Alg1 Unsurları & $\begin{array}{l}\text { Ort. } \\
\text { (Önce) }\end{array}$ & St. Sapma & $\begin{array}{c}\text { Göreceli önem } \\
\text { düzeyi } \\
\text { (Önce) }\end{array}$ & $\begin{array}{l}\text { Ort. } \\
\text { (Sonra) }\end{array}$ & St. Sapma & $\begin{array}{c}\text { Göreceli } \\
\text { önem düzeyi } \\
\text { (Sonra) }\end{array}$ \\
\hline 5-Adana halkı misafirperver ve dost canlısıdır & 4,2434 & 1,08999 & 1 & 4,2623 & 1,11068 & 1 \\
\hline 1-Adana ulaşımı kolay bir şehirdir & 4,0329 & 1,18805 & 2 & 3,8787 & 1,04473 & 13 \\
\hline 8-Adana alışveriş olanaklarına yeterince sahip bir şehirdir & 4,0164 & 1,04505 & 3 & 4,0066 & 1,00889 & 7 \\
\hline 24-Manzara güzelliğine sahip bir şehirdir & 4,0000 & 1,01799 & 4 & 4,0852 & 1,07878 & 4 \\
\hline 20-Başkalarının Adana'yı ziyaret etmesini tavsiye ederim & 3,9803 & 1,18556 & 5 & 4,1639 & 1,08724 & 2 \\
\hline 2-Adana iyi bir iklime sahiptir & 3,9770 & 1,21438 & 6 & 3,8951 & 1,06929 & 12 \\
\hline 4-Adana dinlenme alanları mevcut olan bir şehirdir & 3,9604 & 1,03822 & 7 & 4,0918 & 1,06549 & 3 \\
\hline 21-Adana iyi otellere sahip bir şehirdir & 3,9079 & 1,10716 & 8 & 3,9311 & 1,08451 & 8 \\
\hline 6-Adana tarihi ve kültürel alanlara sahip bir şehirdir & 3,9046 & 1,19160 & 9 & 3,9309 & 1,15119 & 9 \\
\hline $\begin{array}{l}\text { 14-Adana hakkında başkalarına olumlu şeyler söyleyebili- } \\
\text { rim }\end{array}$ & 3,8454 & 1,12829 & 10 & 4,0459 & 1,12407 & 5 \\
\hline 19-Adana hoş bir şehirdir & 3,8328 & 1,12166 & 11 & 4,0428 & 1,18188 & 6 \\
\hline $\begin{array}{l}\text { 7-Adana alışılmadık yaşam biçimleri ve geleneklere sahip } \\
\text { bir şehirdir }\end{array}$ & 3,8284 & 1,35573 & 12 & 3,8623 & 1,25478 & 14 \\
\hline 3-Adana heyecan verici bir şehirdir & 3,7311 & 1,27727 & 13 & 3,8951 & 1,29334 & 11 \\
\hline 18-Adana eğlenceli bir şehirdir & 3,6941 & 1,18370 & 14 & 3,9213 & 1,18407 & 10 \\
\hline 10-Adana ilginç kültürel etkinliklere sahiptir & 3,6361 & 1,16783 & 15 & 3,7895 & 1,12249 & 16 \\
\hline $\begin{array}{l}\text { 25-Keyifli boş zaman etkinlikleri için Adana iyi bir şehir- } \\
\text { dir }\end{array}$ & 3,5475 & 1,24282 & 16 & 3,8355 & 1,17528 & 15 \\
\hline 16-Adana, iyi bir isim ve şöhrete sahiptir & 3,5347 & 3,26297 & 17 & 3,7410 & 3,22232 & 17 \\
\hline 9-Adana diğer yerlerden daha çekicidir & 3,3586 & 1,36664 & 18 & 3,5263 & 1,21023 & 18 \\
\hline 23-Adana iyi gece hayatına sahip bir şehirdir & 3,2838 & 1,31168 & 19 & 3,4638 & 1,29176 & 19 \\
\hline 17-Adana temiz bir şehirdir & 3,2533 & 1,25272 & 20 & 3,3803 & 1,28999 & 20 \\
\hline $\begin{array}{l}\text { 22-Arkadaşlarımın çoğu Adana'yı diğer yerlere tercih edi- } \\
\text { yor }\end{array}$ & 3,1250 & 1,25765 & 21 & 3,2590 & 1,36436 & 23 \\
\hline 15-Adana güvenli bir şehirdir & 3,1217 & 1,38652 & 22 & 3,3344 & 1,15477 & 21 \\
\hline 11-Adana lüks bir şehirdir & 3,0822 & 1,21724 & 23 & 3,3191 & 1,27545 & 22 \\
\hline 13-Adana gelişmiş üst yapıya sahip bir şehirdir & 2,9410 & 1,22600 & 24 & 3,2492 & 1,39201 & 24 \\
\hline 12-Adana gelişmiş alt yapıya sahip bir şehirdir & 2,8721 & 1,28249 & 25 & 3,1480 & 1,31259 & 26 \\
\hline 26-Adana günümüzün moda şehridir & 2,7862 & 1,30637 & 26 & 3,1541 & 1,39582 & 25 \\
\hline
\end{tabular}

Yanıt kategorileri: 1: Kesinlikle katılmıyorum..........5:Kesinlikle katılıyorum

Tablo 3. Portakal Çiçeği Karnavalına katılanların karnavala katılmadan önceki Adana destinasyon imajı algılarına yönelik faktör analizi

\begin{tabular}{|c|c|c|c|c|c|}
\hline Destinasyon İmajı Unsurları önce & $\begin{array}{l}\text { Faktör } \\
\text { yükleri }\end{array}$ & Özdeğer & $\begin{array}{c}\text { Açılanan } \\
\text { varyans }\end{array}$ & $\begin{array}{l}\text { Orta- } \\
\text { lama }\end{array}$ & $\begin{array}{c}\text { Güvenilirlik } \\
\text { katsayısı }\end{array}$ \\
\hline Doğal Çevre ve Gece Hayatı & & 8,677 & 45,668 & 3,600 & ,916 \\
\hline 20-Başkalarının Adana'yı ziyaret etmesini tavsiye ederim & ,763 & & & & \\
\hline 25-Keyifli boş zaman etkinlikleri için Adana iyi bir şehirdir & ,738 & & & & \\
\hline 19-Adana hoș bir şehirdir & ,727 & & & & \\
\hline 23-Adana iyi gece hayatına sahip bir şehirdir & ,705 & & & & \\
\hline 18-Adana eğlenceli bir şehirdir & 652 & & & & \\
\hline 26-Adana günümüzün moda şehridir & ,651 & & & & \\
\hline 24-Manzara güzelliğine sahip bir şehirdir & ,646 & & & & \\
\hline 14-Adana hakkında başkalarına olumlu șeyler söyleyebilirim & 642 & & & & \\
\hline 15-Adana güvenli bir șehirdir & ,602 & & & & \\
\hline 21-Adana iyi otellere sahip bir şehirdir & ,579 & & & & \\
\hline Alt ve Üst Yapı Olanakları & & 1,666 & 8,768 & 2,965 & ,843 \\
\hline 12-Adana gelişmiș alt yapıya sahip bir șehirdir & ,882 & & & & \\
\hline 13-Adana gelişmiş üst yapıya sahip bir şehirdir & ,838 & & & & \\
\hline 11-Adana lüks bir şehirdir & ,649 & & & & \\
\hline Tarihi ve Kültürel Çekicilikler & & 1,187 & 6,247 & 3,791 & ,733 \\
\hline 7-Adana alışılmadık yaşam biçimleri ve geleneklere sahip bir șehirdir & 847 & & & & \\
\hline 6-Adana tarihi ve kültürel alanlara sahip bir şehirdir & 654 & & & & \\
\hline 10-Adana ilginç kültürel etkinliklere sahiptir & 616 & & & & \\
\hline Ulaşım ve Konukseverlik & & 1,040 & 5,472 & 4,077 & ,690 \\
\hline 1Adana ulaşımı kolay bir şehirdir & ,779 & & & & \\
\hline 4-Adana dinlenme alanları mevcut olan bir şehirdir &, 672 & & & & \\
\hline 5-Adana halkı misafirperver ve dost canlısıdır &, 565 & & & & \\
\hline
\end{tabular}

Varimax rotasyonlu temel bileşenler analizi. Açıklanan toplam varyans: $\% 66,155$. KMO örneklem yeterliliği: \%93; Bartlett küresellik testi: $X^{2}: 3246,150$, s.d.: 171, p $<0.000$; Genel ortalama: 3,603; Ölçeğin tamamı için Alpha: .937;

Yanıt kategorileri: 1:Kesinlikle katılmıorum.. 5:Kesinlikle katılıyorum 
Birinci faktöre yüklenen maddeler incelendiğinde, destinasyonun sahip olduğu özelliklerle ilgili olduğu görülmektedir. Bu açıdan faktöre "Doğal Çevre ve Gece Hayatı" adı verilmiştir. Birinci faktör, on maddeden oluşmakta ve toplam varyansın \%45,668'ini oluşturmaktadır. İkinci faktör, "Adana gelişmiş alt yapıya sahip bir şehirdir $(, 882)$ ", "Adana gelişmiş üst yapıya sahip bir şehirdir (,838)" ve "Adana lüks bir şehirdir (,649)" maddelerinden oluşmaktadır. Bu yüzden faktöre "Alt ve Üst Yapı Olanakları" adı verilmiştir. Bu faktör, toplam varyansın \%8,7'sini açıklamaktadır. "Tarihi ve Kültürel Çekicilikler" adı verilen üçüncü faktör, üç maddeden oluşmakta ve toplam varyansın \%6,2'sini açıklamaktadır. Faktör, "Adana alışılmadık yaşam biçimleri ve geleneklere sahip bir şehirdir (,847)", "Adana tarihi ve kültürel alanlara sahip bir şehirdir (,654)" ve "Adana ilginç kültürel etkinliklere sahiptir (,616)" şeklinde sıralanmıştır. Dördüncü faktör, dört maddeden oluşmuş ve toplam varyansın \%5,4'ünü açıklamaktadır. Faktöre yüklenen maddeler incelendiğinde destinasyonun ulaşımı ile ilgili unsurları kapsadığı görülmektedir. Bu açıdan bu faktöre "Ulaşım ve Konukseverlik" adı verilmiştir. Bu faktöre "Adana ulaşımı kolay bir şehirdir (,779)", "Adana dinlenme alanları mevcut olan bir şehirdir (,672)" ve "Adana halkı misafirperver ve dost canlısıdır (,565)" adlı maddeler yüklenmiş̧ir.

$\mathrm{AS}_{3}$ : Yerli turistlerin karnavala katıldıktan sonraki Adana destinasyon imajına yönelik algı boyutları nelerdir?

Karnavala katılım sonrası, Barlett Küresellik testinin $(3469,881)$ anlamlı çıkması $(p<0,000)$ ve Kaiser-MeyerOlkin testine $(0,939)$ göre örneklem büyüklüğü yeterli olduğu tespit edilmiştir. Faktör analizi, toplam yirmi altı maddeye uygulanmış, faktörlere hiç yüklenmeyen $(3,16,17$ ve 21$)$ maddeler analizden çıkarılmıştır. Yapılan faktör analizine göre, 22 madde dört boyut altında toplanmış ve toplam varyansın \%60'ını açıklamıştır. Faktörlere "Doğal Çevre ve Gece Hayatı", "Tarihi ve Kültürel Çekicilikler", "Ulaşım ve Konukseverlik” ve "Alt ve Üst Yapı Olanakları" adları verilmiştir (Tablo 4).

Tablo 4. Portakal Çiçeği Karnavalına katılanların karnavala katıldıktan sonra Adana destinasyon imajına yönelik faktör analizi

\begin{tabular}{|c|c|c|c|c|c|}
\hline Destinasyon İmajı Unsurları (Sonra) & $\begin{array}{l}\text { Faktör } \\
\text { yükleri }\end{array}$ & Özdeğer & $\begin{array}{c}\text { Açıklanan } \\
\text { varyans }\end{array}$ & Ortalama & $\begin{array}{c}\text { Güveni- } \\
\text { lirlik kat- } \\
\text { sayis1 }\end{array}$ \\
\hline Doğal Çevre ve Gece Hayatı & & 9,568 & 43,490 & 3,742 & 887 \\
\hline 25-Keyifli boş zaman etkinlikleri için Adana iyi bir șehirdir & 708 & & & & \\
\hline 18-Adana eğlenceli bir şehirdir & .676 & & & & \\
\hline 26-Adana günümüzün moda șehridir & 654 & & & & \\
\hline 23-Adana iyi gece hayatına sahip bir șehirdir & 647 & & & & \\
\hline 19-Adana hoș bir şehirdir & 642 & & & & \\
\hline 20-Başkalarının Adana'yı ziyaret etmesini tavsiye ederim & 607 & & & & \\
\hline 24-Manzara güzelliğine sahip bir şehirdir & ,599 & & & & \\
\hline 22-Arkadaşlarımın çoğu Adana'yı diğer yerlere tercih ediyor & ,534 & & & & \\
\hline Tarihi ve Kültürel Çekicilikler & & 1,601 & 7,276 & 3,923 & 868 \\
\hline 8-Adana alışveriş olanaklarına yeterince sahip bir șehirdir & ,742 & & & & \\
\hline 7-Adana alışılmadık yaşam biçimleri ve geleneklere sahip bir şehirdir & 705 & & & & \\
\hline 6-Adana tarihi ve kültürel alanlara sahip bir șehirdir & 675 & & & & \\
\hline 10-Adana ilginç kültürel etkinliklere sahiptir & ,650 & & & & \\
\hline 4-Adana dinlenme alanları mevcut olan bir șehirdir & ,622 & & & & \\
\hline 5-Adana halkı misafirperver ve dost canlısıdır & 610 & & & & \\
\hline 9-Adana diğer yerlerden daha çekicidir & .537 & & & & \\
\hline Ulaşım ve Konukseverlik & & 1,139 & 5,179 & 3,789 & ,742 \\
\hline 1-Adana ulaşımı kolay bir şehirdir & ,743 & & & & \\
\hline 2-Adana iyi bir iklime sahiptir & 603 & & & & \\
\hline 15-Adana güvenli bir șehirdir & 576 & & & & \\
\hline 14-Adana hakkında başkalarına olumlu șeyler söyleyebilirim & ,548 & & & & \\
\hline Alt ve Üst Yapı Olanakları & & 1,090 & 4,955 & 3,241 & ,783 \\
\hline 12-Adana gelișmiș alt yapıya sahip bir şehirdir & ,814 & & & & \\
\hline 13-Adana gelișmiș üst yapıya sahip bir şehirdir &, 753 & & & & \\
\hline 11-Adana lüks bir şehirdir & 697 & & & & \\
\hline
\end{tabular}

$\mathrm{AS}_{4}$ : Yerli turistlerin karnavala katılım öncesi ve karnavala katılım sonrası destinasyon imajı algıları arasında anlamlı bir farklılık var mıdır?

Turistlerin gezmek istedikleri destinasyona gelmeden önce destinasyona yönelik sahip olunan destinasyon imajı ile destinasyonu deneyimledikten sonra sahip olunan destinasyon imajı algılarını karşılaştırmak için eşleştirilmiş örneklem $t$ testi (Paired Sample $t$ test) yapılmıştır (Tablo 5). 
Tablo 5. Karnavala Katılım Öncesi ve karnavala katılım sonrası destinasyon imajı eşleştirilmiş örneklem testi

\begin{tabular}{|c|c|c|c|c|c|c|c|}
\hline \multicolumn{2}{|r|}{ Faktör Adları } & Ort. & Fark & S.S. & $\mathrm{t}$ & df & Sig. \\
\hline $\begin{array}{l}1 . \\
\text { EŞ }\end{array}$ & $\begin{array}{l}\text { Doğal Çevre ve Gece Hayatı } \\
\text { Sonrası } \\
\text { Öncesi }\end{array}$ & $\begin{array}{r}3,74 \\
3,59 \\
\end{array}$ & 0,15 &, 74315 & 3,580 & 302 &, $000 * * * *$ \\
\hline $\begin{array}{l}2 . \\
\text { EŞ }\end{array}$ & $\begin{array}{l}\text { Tarihi ve Kültürel Çekicilikler } \\
\text { Sonrası } \\
\text { Öncesi }\end{array}$ & $\begin{array}{l}3,92 \\
3,79\end{array}$ & 0,17 &, 80661 & 2,786 & 301 &, $006 * * *$ \\
\hline $\begin{array}{l}3 . \\
\text { EŞ }\end{array}$ & $\begin{array}{l}\text { Ulaşım ve Konukseverlik } \\
\text { Sonrası } \\
\text { Öncesi }\end{array}$ & $\begin{array}{l}3,79 \\
4,08 \\
\end{array}$ & $-0,29$ & 86039 & $-5,798$ & 302 &, $000 * * * *$ \\
\hline $\begin{array}{l}4 . \\
\text { EŞ }\end{array}$ & $\begin{array}{l}\text { Alt ve Üst Yapı Olanakları } \\
\text { Sonrası } \\
\text { Öncesi }\end{array}$ & $\begin{array}{l}3,24 \\
2,96\end{array}$ & 0,28 & 89063 & 5,409 & 303 &, $000 * * *$ \\
\hline
\end{tabular}

Not: $*$ p $<.05 ; * * \mathrm{p}<.01 ; * * * \mathrm{p}<.001$

Yapılan eşleştirilmiş örneklem $t$ testine (Paired Sample $t$ test) göre, yerli turistlerin Karnavala katılmadan önce zihinlerindeki Adana destinasyon imajı ile Karnavala katıldıktan sonra Adana destinasyon imajı arasında istatistiksel olarak anlamlı bir farklılık olduğu $(\mathrm{p}=0,000<0,050)$ tespit edilmiştir. Tablo 5 'ten de görülebileceği gibi, turistlerin karnavala katılmadan önce Adana destinasyon imajı ile ilgili sahip oldukları imaj boyutlarından "Doğal Çevre ve Gece Hayatı”, "Tarihi ve Kültürel Çekicilikler" ve "Alt ve Üst Yapı Olanakları" algıları, karnavala katıldıktan sonra, önceki imaj algılarına göre olumlu gelişmeler olduğu görülmektedir. Bununla birlikte, "Ulaşım ve Konukseverlik" boyutuna yönelik algının karnavala katıldıktan sonra düşük bir algıya dönüştüğü görülmektedir.

Yerli turistlerin karnavala katıldıktan sonra edindikleri genel destinasyon imajı ortalamasının $(3,74)$ karnavala katılmadan önceki mevcut destinasyon imajı ortalamasının $(3,60)$ değişim oranına $(0,14)$ bakıldığında yerli turistlerin genel olarak Adana destinasyon imajı algılarının yüksek olduğu tespit edilmiştir. Diğer bir ifadeyle, yerli turistlerin Karnavala katıldıktan sonra Adana destinasyon imajına yönelik algılarının Karnavala katılmadan önceki Adana destinasyon imajı algılarına oranla daha yüksek düzeye çıktığı belirlenmiştir. Bununla birlikte, en az değişim yaşanan destinasyon imajı boyutunun "Doğal Çevre ve Gece Hayatı $(0,15)$ " boyutu olduğu belirlenmiştir.

\section{Sonuç ve öneriler}

Destinasyonlara yönelik yapılan ziyaretlerin, turistlerin zihnindeki yeri ve destinasyona yönelik imaj farklılıklarının belirlenmesi, destinasyon yöneticileri ve pazarlayıcıları açısından destinasyonun pazarlamasında geliştirilecek stratejiler açısından büyük önem taşımaktadır. Bu açıdan, çalışmada elde edilen sonuçların destinasyon yöneticileri ve pazarlayıcıları tarafından dikkate alınması önerilmektedir. Bu çalışmada, "turistlerin karnavala katılmadan önce ve karnavala katıldıktan sonra Adana destinasyon imajına yönelik algılarında anlamlı bir farklılık vardır" sorusundan hareket edilmiştir. Dolayısıyla, çalışmada, VI. Uluslararası Portakal Çiçeği Karnavalı'na katılan yerli turistlerin karnavala katılmadan önceki ve sonraki Adana destinasyon imajına yönelik algılarının belirlenmesi ve destinasyon imajı algıları arasında fark varsa bunun ortaya koyulması amaçlanmıştır.

Çalışmada, öncesi ve sonrası destinasyon imajındaki tüm boyutlarda değişim olduğu tespit edilmiştir. Bu bulgu, öncesi ve sonrası imaj çalışmaları (Hunt, 1975; Lin vd., 2013; Jani \& Nguni, 2014; Güçlü \& Yılmaz, 2020) ile örtüşmektedir. Destinasyonu farklı nedenlerle ziyaret etmeden önce turistlerin sahip oldukları imaj ile destinasyonu gezdikten ve destinasyonda yaşanılan deneyimlerden sonra sahip olunan imaj arasında farklılıklar olduğu yapılan çalışmalarla (Lim vd., 2014; Yılmaz vd., 2009; Wang \& Davidson, 2010) desteklenmiştir. Bu fark olumlu olabileceği gibi olumsuz veya nötr olarak gerçekleşebilmektedir (Güçlü \& Y1lmaz, 2020: 176).

Sonuç olarak, karnavala katılmadan önce yerli turistlerin sahip oldukları destinasyon imajı ile karnavala katıldıktan sonra edinilen Adana destinasyon imajı arasında istatistiksel olarak anlamlı bir farklılık olduğu bulunmuştur. Destinasyon imajı boyutlarından, "Doğal Çevre ve Gece Hayatı", "Tarihi ve Kültürel Çekicilikler" ve "Alt ve Üst Yapı Olanakları" boyutlarında, yerli turistlerin karnavala katıldıktan sonra, önceki imaj algılarına göre olumlu farklılıklar olduğu belirlenmiştir. Bu bulgu, destinasyon imajına yönelik yapılan (Yılmaz vd., 2009; Hunt, 1975; Lim, Chew, Lim \& Liu, 2014; Güçlü, 2017; Güçlü \& Yılmaz, 2020) benzer bulgulara sahip çalışmalarla desteklenmiştir. Dolayısıyla, yerli turistlerin karnavala katıldıktan sonra destinasyon imajı algılarının, önceki destinasyon algılarına oranla olumlu yönde geliştiği belirlenmiştir. "Ulaşım ve Konukseverlik" boyutu algısının karnavala katıldıktan sonra daha düşük bir algıya sahip olmasından dolayı bu boyuta yüklenen maddeler incelendiğinde, 
ulaşım ve iklimin ağırlıklı olduğu ve bu konularda yaşanan olumsuz deneyimlerin sonuca etkisi olduğu düşünülmektedir. Dolayısıyla, destinasyon yöneticilerine bu konuda yaşanan olumsuzlukları tespit edecek çalışmaların yapılması önerilebilir. Bununla birlikte, destinasyonun güvenilir olduğuna yönelik reklam ve tanıtım çalışmaları yapılması önerilebilir. Ayrıca, festival internet sitesinin içeriğinin etkin olması ile siteden ziyaretçilere doğrudan mesajlar iletilebilir. Öte yandan, en az değişime sahip destinasyon imajı boyutunun "Doğal Çevre ve Gece Hayatı" boyutu olduğu tespit edilmiştir. Dolayısıyla, destinasyon yöneticileri Adana'nın doğal çevre ve gece hayatına yönelik yapacakları reklam ve tanıtım faaliyetlerinde Adana destinasyon imajının turistin zihninde olumlu bir şekilde konumlanmasına yardımcı olacak bilgilendirici ve teşvik edici tanıtımların yapılması önerilebilir.

Adana'nın turizm imajı ile ilgili yapılan çalışmalar (Saçlı \& Ersöz, 2019; Dinler, 2019; Ballı, 2016; Çeviker, 2019; Sahilli Birdir \& Toksöz, 2017) mevcut olmakla birlikte, Adana'nın ziyaret öncesi ve sonrası imajının belirlenmesine yönelik bir araştırma olmadığı belirlenmiştir. Bu açıdan bu çalışma, alanyazına katkı sağlama potansiyeline sahip olmakla birlikte, Adana'nın sahip olduğu olumlu ve olumsuz imajların hangilerinin olduğu belirlenmeye çalışılmıştır. Uluslararası Portakal Çiçeği Karnavalı'na katılan yerli turistlerle sınırlandırılan bu çalışma, Adana'yı farklı amaçlarla ziyaret eden yabancı turistlerle de yapılabilir. Daha sonra yapılacak çalışmalarda destinasyonlarda gerçekleştirilen etkinliklerin katılım öncesi ve sonrası destinasyon imajına yönelik farklılıkları tespit edecek çalışmalar yapılarak destinasyon yöneticilerine katkı sağlanabilir.

\section{Yazarların katkı oranı beyanı}

Yazarlar makalenin veri toplama, veri analizi, raporlaştırma ve diğer aşamalarından eşit düzeyde sorumlu olduğunu beyan ederler.

\section{Çıkar Çatışması}

Bu çalışmada yazarlar tarafindan herhangi bir çıkar çatışması belirtilmemiştir.

\section{Etik Kurul Onayı}

Bu araştırmanın verileri 7-8 Nisan 2018'de toplanmıştır. Tüm sorumluluk yazarlarına aittir.

\section{Kaynakça}

Anil, N. K. (2012). Festival visitors' satisfaction and loyalty: An example of small, local, and municipality organized festival. Tourism. Vol. 60/ No. 3/255-271.

Arcodia, C. \& Dickson, C. (2013). Tourism Field Studies: Experiencing the Carnival of Venice Journal of Hospitality \& Tourism Education, 25 (3), 146-155.

Artuğer, S., \& Çetinsöz, B. C. (2014). Destinasyon imajı ile destinasyon kişiliği arasındaki ilişkiyi belirlemeye yönelik bir araştırma. İşletme Araştırmaları Dergisi, 6(1), 366-384.

Axelsen, M. \& Swan, T. (2010). Designing Festival Experiences to Influence Visitor Perceptions: The Case of a Wine and Food Festival. Journal of Travel Research 49(4), 436-450.

Ballı, E. (2016). Gastronomi Turizmi Açısından Adana Sokak Lezzetleri, J. of Tourism and Gastronomy Studies, 4 (1), 3-17.

Baloğlu, Ş. (1999). A path analytic model of visitation intention involving information sources, socio-psychological motivations, and destination image. Journal of Travel and Tourism Marketing, 8(3), 81-91.

Baloğlu, Ş., \& McCleary, K. W. (1999). A model of destination image formation. Annals of Tourism Res. 26(4), 868-897.

Beerli, A. \& Martin, J. D. (2004). Factors influencing destination image. Annals of tourism research, 31(3), 657-681.

Bekar, A., Kocatürk, E., \& Sürücü, Ç. (2017). Gastronomi Festivallerinin Algılanan Destinasyon İmajına ve Tekrar Ziyaret Etme Niyetine Etkisi: Fethiye Yeşilüzümlü ve Yöresi Kuzugöbeği Mantar Festivali Örneği, J. of Tourism and Gastronomy Studies 5(2), 28-36.

Benli, S. (2014). Yöresel Lezzet Deneyiminin Destinasyon İmajı ve Destinasyon Sadakati Üzerine Etkisi: Mersin'i Ziyaret Eden Yerli Turistler Üzerinde Bir Araştırma. Yüksek Lisans Tezi. Mersin Üniversitesi, SBE. Turizm İ.ABD. Mersin.

Chen, J. S., \& Uysal, M. (2002). Market positioning analysis: A hybrid approach. Annals of Tourism Res., 29(4), 987-1003.

Crompton, J.L. (1979). An assessment of the image of Mexico as avacation destination and the influence of geographical locationupon that image. Journal of Travel Research, 17(4) (Spring), 18-23.

Cronbach, L. J. (1990). Essentials of Psyhological Testing, (5th ed), New York: Harper Collins Publisher.

Coşkun, R., Altunışık, R., Bayraktaroğlu, S. \& Yıldırım, E. (2007). Sosyal Bilimlerde Araştırma Yöntemleri. Sakarya: Sakarya Yayıncilik.

Çanakçı, S. D., Çanakçı, T., \& Geçgin, E. (2019). Kars İlinin Destinasyon İmajı ve Doğu Ekspres’i Deneyimi. Opus Uluslararası Toplum Araştırmaları Dergisi, 11 (18), 1876-1896.

Çeviker, K. (2019). Turizm Faaliyetlerinin Yerel Halk Tarafından Nasıl Algılandığının Analizi: Adana Örneği. Yayınlanmamış Yüksek Lisans Tezi. Necmettin Erbakan Üniversitesi, Sosyal Bilimler Enstitüsü. Konya. 
Dinler, B. V. (2019). Adana İli Gastronomik Kimliğinin Destinasyon Markalaşması Açısından Değerlendirilmesi. Yayınlanmamış Yükssek Lisans Tezi. Nevşehir Hacı Bektaş Veli Üniversitesi. SBE. Turizm İşletmeciliği ABD. Nevşehir.

Echtner, C. M., \& Ritchie, J. B. (1991). The meaning and measurement of destination image. J. of tourism studies, 2(2), 2-12.

Gibson, J., Conell, J., Waitt G., \& Walmsley, J. (2011). Gibson, C., \& Connell, J. (Ed.). Festival Places: Revitalising Rural Australia (Vol.27). Channel View Publications.

Güçlü, C. (2017). Turizm Deneyiminin Destinasyon İmajı Üzerindeki Etkisi. Alanya Örneği. Yayınlanmamış Doktora Tezi. Akdeniz Üniversitesi, Sosyal Bilimler Enstiütüsü. Antalya.

Güçlü, C., \& Yılmaz, Y. (2020). Tatil Öncesi ve Sonrası Destinasyon İmajı Karşılaştırması: Alanya Örneği, Seyahat ve Otel İşletmeciliği Dergisi, 17(2), 173-185. DOI:10.24010/soid.674868

Gül, K., Erdem, B., \& Gül, M. (2013). Yerel Festivallerin Etkinliğine Bağlı Ziyaretçi Kazanımları: Sındırgı Yağcıbedir Festivali Örneği. Süleyman Demirel Üniversitesi İktisadi ve İdari Bilimler Fakültesi Dergisi, 18(2), 213-239.

Hair, J.F., Black, W., Babin, B., \& Andersen, R.E. (2010). Multivariate Data Analysis: A Global Perspective. NJ: Pearson Prentice-Hall.

Hunt, J.D. (1975). Image as a factor in tourism development. Journal of Travel Research, 13(3) (Winter), 1-7.

Jani, D. \& Nguni, W. (2014). Variation Of Destination Image With Visitation Status: A Case Of Inbound Tourists To Tanzania. 12th Apacchrie Conference. Tanzania, 1-9.

Karagöz, D. (2006). Etkinlik Turizmi Ve Etkinlik Turizmi Bağlamında Yabancı Ziyaretçi Harcamalarının Ekonomiye Etkisi: Formula 12005 Türkiye Grand Prix Örneği. Yayınlanmamış Yüksek Lisans Tezi, Anadolu Üniversitesi, Eskişehir.

Kim, S. S., Prideaux, B., \& Chon, K. (2010). A Comparison Of Results Of Three Statistical Methods To Understand The Determinants Of Festival Participants' Expenditures. International Journal Of Hospitality Management, 29(2), 297-307.

Kim, H., \& Richardson, S. L. (2003). Motion picture impacts on destination images. Annals of Tourism Res.30(1), $216-237$.

Lee, Jenny (Jiyeon) Lee, Gerard Kyle \& David Scott (2012). The Mediating Effect of Place Attachment on the Relationship between Festival Satisfaction and Loyalty to the Festival Hosting Destination. Journal of Travel Research,1-14.

Lim, C., Chew, S. L., Lim, Z. Y., \& Liu, W. (2014). Pre-and post-visit perceptions of youth tourists to China. Journal of China Tourism Research, 10(2), 236-255. DOI: 10.1080/19388160.2013.849637

Lin, M. J., Hsueh, Y. H., Liu J. Q., Huang, W. H. \& Min, X. (2013). Comparing Tourist Destination Images Between Pre-Trip And Post-Trip. The Asian Conference On Arts and Humanities Official Conference Proceedings. Osaka, Japan, 160-167.

Nakip, M. (2003). Pazarlama Araştırmaları Teknikler ve (Spss Destekli) Uygulamalar. 1. Baskı. Ankara: Seçkin Yayıncılık.

Nisanda Adanada (2018). [URL:http://www.nisandaadanada.com (Erişim Tarihi 05.08.2018).

Penpece, D. (2014). Festivallerin Pazarlanması: Türkiye'deki Uluslararası Festivaller Üzerinde Bir Araştırma. Ç.Ü. Sosyal Bilimler Enstitüsü Dergisi, 23(1), 193-210.

Rivera, M.A., Hara, T. \& Kock, G. (2008). Economic İmpact Of Cultural Events: The Case Of The Zora Festival. Journal Of Heritage Tourism, 3(2), 121-137.

Saçlı, Ç., \& Ersöz, B. (2019). Festival Katılımcılarının Destinasyon İmajı Algılarını Oluşturan Faktörlerin Belirlenmesi: Adana Şalgam ve Kebap Festivali Örneği. Journal of Tourism and Gastronomy Studies, 7 (1), 185-204.

Saçlı, Ç., Ersöz, B., \& Kahraman, C. Ö. (2019), "Etkinlik Katılımcılarının Destinasyon İmajı Algılarının Tekrar Ziyaret Etme Eğilimleri Üzerine Etkisi: Portakal Çiçeği Karnavalı Örneği”, Çukurova Üniversitesi SBE Dergisi, Cilt 28 (1), 178-190.

Sahilli Birdir, S., Toksöz, D., \& Bak, E. (2016). Karnavala Katılım Güdüleri: IV . Adana Uluslararası Portakal Çiçeği Karnavalı Örneği. Çă̆ Üniversitesi Sosyal Bilimler Dergisi 13(1), 21-39.

Sahilli Birdir, S. \& Toksöz, D. (2017). Portakal Çiçeği Karnavalı'na Katılan Gençlerin Adana Destinasyon İmajı Algıları, 1. Uluslararası Turizmin Geleceği Kongresi: Ínovasyon, Girişimcilik ve Sürdürülebilirlik Kongresi (Futourism), 880-888.

San Martín, H. \& Del Bosque, I. A. R. (2008). Exploring the cognitive-affective nature of destination image and the role of psychological factors in its formation. Tourism management, 29 (2), 263-277.

Tümbek Tekeoğlu, A. N., \& Gökseven, K. (2019). Bir Şehrin Festivaller İle Markalaşması ve Pazarlanması Olarak Adana'nın İncelenmesi. Turan: Stratejik Araştırmalar Merkezi, 11(42), 345-357.

Um, Seoho, \& Crompton, J.L. (1990). Attitude determinants intourism destination choice. Annals of Tourism Res. 17, 432-448

Wang, Y. \& Davidson, M. C. (2010). Pre-and post-trip perceptions: An insight into Chinese package holiday market to Australia. Journal of Vacation Marketing, 16(2), 111-123.

Wong, Jose, Hung-Che Wu \& Ching-Chan Cheng (2014). An Empirical Analysis of Synthesizing the Effects of Festival Quality, Emotion, Festival Image and Festival Satisfaction on Festival Loyalty: A Case Study of Macau Food Festival. International Journal of Tourism Research, DOI: 10.1002/jtr.2011.

Wu, Hung-Che \& Chi-Han Ai (2015). A study of festival switching intentions, festival satisfaction, festival image, festival affective impacts, and festival quality. Tourism and Hospitality Research, 1-27.

Yayla, Ş. (2017). Yöresel Yemek Festivaline Katılım Motivasyonu İle Festivallerin Destinasyon İmajına ve Davranışsal Niyetlere Etkisi. Yayınlanmamış Yüksek Lisans Tezi. Eskişehir Osmangazi Üniversitesi, SBE, Eskişehir.

Yazıcıoglu, Y., \& Erdoğan, S. (2004). SPSS Uygulamalı Bilimsel Araştırma Yöntemleri. Ankara: Detay Yayıncılık.

Yılmaz, Y., Yılmaz, Y., İçigen, E. T., Ekin, Y. \& Utku, B. D. (2009). Destination Image: A Comparative Study on Pre and Post Trip Image Variations, Journal of Hospitality Marketing \& Management, 18 (5), 461- 479.

Yükselen, C. (2000). Pazarlama Araştırmaları. 1. Baskı. Ankara: Detay Yayıncılık. 


\section{Extended Abstract}

Carnivals organized in many parts of the world increase the recognition of the destination, have a positive effect on the image of the destination and contribute to the destination economically, socially and culturally (Rivera et al., 2008: 128; Kim et al., 2010: 297; Axelsen and Swan, 2010; Gül et al., 2013; Single, Kocatürk \& Sürücü, 2017: 29-32). Moreover, carnivals which are held in different periods of the tourism season allowing tourists to visit the destination outside of the season and this allows the tourism season to extend (Arcodia \& Dickson, 2013: 148). There are any studies on the tourism image of Adana (Saçlı \& Ersöz, 2019; Dinler, 2019; Ball1, 2016; Çeviker, 2019; Sahilli Birdir \&Toksöz, 2017) have been conducted. However, little research has been done to identify differences focused on image measurement before and after the visit. To fill this gap, the aim of this study is to determine the perceptions of tourists participating in the $6^{\text {th }}$ International Orange Blossom Carnival towards the Adana destination image before and after participating in the carnival and to reveal the differences between the Adana destination image before and after participating in the carnival.

The universe of the research was composed of the tourists participating in the $6^{\text {th }}$ International Orange Blossom Carnival. The sample mass was selected that has the ability to represent the universe. In the study, the "convenience sampling method" was chosen among the non-random sampling methods. The questionnaire included an image scale consisting of 26 items including evaluations of Adana before and after attending the $6^{\text {th }}$ International Orange Blossom Carnival. In the study, a 5-point Likert type ("(1) strongly disagree"..."(5) strongly agree") scale was used.

A pre-test (06 April 2018) was conducted with 16 local tourists to test the reliability of the questionnaire form. The destination image Cronbach Alpha value before participation in the carnival is found to be 0.908 , and the destination image after participating in the carnival is 0.923 . It has been found that the questionnaire form developed is sufficient in terms of reliability. The data for the main application of the study were collected face to face between 07-08 April 2018. A total of 320 questionnaires were collected from the participants and 305 questionnaires were analyzed. The destination image Cronbach Alpha value before participation in the carnival was determined as 0.928 , and the destination image Cronbach Alpha value after participating in the carnival was determined as 0.927 . In the research, descriptive analyzes were made first. Then, factor analysis was conducted to determine the dimensions of the destination image perceptions before and after participating in the carnival. In addition, ttest, variance analysis and other relevant analyzes were performed.

$49.5 \%$ of the participants are "female" and 50.5\% are "male". 56.7\% are "single" and $43.3 \%$ are married. $50.4 \%$ are in the "21-30" age range. Participants in the age range of "31-40" with a rate of 23.8\%, "41-50" with a rate of $16 \%$ and " 51 and over" with a rate of $9.8 \%$ follow this. $63 \%$ of the participants are university graduates. Participants were "student (26.2\%)", "self-employment (23.6\%)", "civil servant (17.7\%)", "manager (10.5)" and "worker $(9.8 \%)$ ". It has been determined that $58.4 \%$ of the majority of the participants are in the "middle" income group.

In the study, it was found that there is a statistically significant difference between the destination image of local tourists before participating in the carnival and after participating in the carnival. Among the dimensions of the destination image, "Natural Environment and Nightlife", "Historical and Cultural Attractions" and "Infrastructure and Superstructure Facilities", it has been determined that there are positive differences compared to the previous image perceptions of local tourists after participating in the carnival. This finding is supported by studies with similar findings (Y1lmaz et al., 2009; Hunt, 1975; Lim, Chew, Lim \& Liu, 2014; Güçlü, 2017; Güçlü \& Y1lmaz, 2020). Therefore, it was found that the destination image perceptions of tourists after participating in the carnival improved in a positive way compared to the previous destination perceptions.

Since the perception of the "Transportation and Hospitality" dimension has a lower perception after joining the carnival, it may be recommended to conduct studies to identify the negativities experienced in this regard to destination managers. On the other hand, it was determined that the dimension of the destination image with the least change is the "Natural Environment and Nightlife" dimension. Therefore, it may be suggested to make informative and encouraging promotions that will help the Adana destination image to be positively positioned in the mind of the tourist in the advertising and promotion activities that the destination managers will make for Adana's tourism industry.

Limited to tourists participating in the $6^{\text {th }}$ International Orange Blossom Carnival, this study can also be done with foreign tourists visiting Adana for different purposes. In future studies, contribution to destination managers can be made by conducting studies to determine the differences in the destination image before and after the participation of the activities held at the destinations. 